\section{Obama appoints bioethics panel to offer practical advice}

In April, President Barack Obama named 11 more members to the Presidential Commission for the Study of Bioethical Issues. They will join commission chair Amy Gutmann, president of the University of Pennsylvania, and commission vice-chair James Wagner, Emory University president, who were appointed last year. The new commission replaces the controversial President's Council on Bioethics set up by President George W. Bush in 2001, which contained several members of the pro-life lobby.

The 13 newly appointed commissioners are not preponderantly "professional bioethicists" but rather come from other fields "at the intersection of science, technology and ethics" (Table 1). Part of the idea with this departure from mainstream bioethicists is to reach beyond biology and medicine to involve those working with "hardware, software and related technologies such as robotics," officials say. The president's new panel is expected to react rapidly and provide practical guidance, a radical departure from the Bush-era commission, which favored discussion and was often accused of producing reports with ideological leanings.

Obama's commission differs from the Bush council in several ways. First, the new commission is lean, with only 13 members to "keep the group nimble and facilitate discussion and consensus building."

Second, its members are asked not to engage in "arcane philosophical discussions" but to provide the president and administration with practical, policy-oriented, ethics-based recommendations. For that reason, the commission includes several insiders who work for federal agencies, a shift that is meant to keep discussions and advice from straying outside "the complex framework of federal policymaking processes and procedures."

Jeffrey L Fox

Table 1 Who's who-new bioethics appointees

\begin{tabular}{|c|c|c|}
\hline Panel member & Group & Post \\
\hline Lonnie Ali & Advocate & $\begin{array}{l}\text { Wife of former heavyweight boxing champion Muhammad Ali is } \\
\text { an advocate for research on Parkinson's disease }\end{array}$ \\
\hline Anita L. Allen & Academic & $\begin{array}{l}\text { Professor of law and philosophy and also deputy dean at the } \\
\text { University of Pennsylvania Law School, and senior fellow in the } \\
\text { Bioethics Department, School of Medicine; served in the 1990s } \\
\text { on the National Advisory Council for Human Genome Research }\end{array}$ \\
\hline John D. Arras & Academic & $\begin{array}{l}\text { Porterfield professor of biomedical ethics and professor of } \\
\text { philosophy at the University of Vierginia; longtime fellow of the } \\
\text { Hastings Center }\end{array}$ \\
\hline Barbara Atkinson & Academic & $\begin{array}{l}\text { Executive vice chancellor of the University of Kansas Medical } \\
\text { Center and executive dean of the University of Kansas School } \\
\text { of Medicine }\end{array}$ \\
\hline Nita A. Farahany & Academic & $\begin{array}{l}\text { Associate professor of law and philosophy at Vanderbilt } \\
\text { University; focuses on legal, philosophical and social issues aris- } \\
\text { ing from developments in behavioral genetics and neuroscience }\end{array}$ \\
\hline Alexander Garza & Government & $\begin{array}{l}\text { Assistant secretary for health affairs and chief medical officer } \\
\text { for the Department of Homeland Security; specialized in emer- } \\
\text { gency medicine }\end{array}$ \\
\hline Christine Grady & Government & $\begin{array}{l}\text { Acting chief of the Department of Bioethics at the National } \\
\text { Institutes of Health Clinical Center; focuses on research sub- } \\
\text { ject recruitment, incentives and vulnerability }\end{array}$ \\
\hline Stephen L. Hauser & Academic & $\begin{array}{l}\text { Professor and chair of the Department of Neurology at the } \\
\text { University of California, San Francisco; focuses on the genetic } \\
\text { and immune basis of multiple sclerosis }\end{array}$ \\
\hline Raju Kucherlapati & Academic & $\begin{array}{l}\text { Professor in the Harvard Medical School Department of Genetics } \\
\text { and the Department of Medicine at Brigham and Women's } \\
\text { Hospital; was the first scientific director of the Harvard Medical } \\
\text { School-Partners Healthcare Center for Genetics and Genomics }\end{array}$ \\
\hline Nelson Michael & Academic & $\begin{array}{l}\text { Director of the Division of Retrovirology at the Walter Reed } \\
\text { Army Institute of Research; directs the US Military HIV } \\
\text { Research program }\end{array}$ \\
\hline Daniel Sulmasy & Academic & $\begin{array}{l}\text { Franciscan Friar and chair in medicine and ethics in the } \\
\text { Department of Medicine and Divinity School, and associate } \\
\text { director of the MacLean Center for Clinical Medical Ethics at } \\
\text { the University of Chicago }\end{array}$ \\
\hline
\end{tabular}

\section{IN brief}

\section{GSK's RNA splash}

Antisense-drug developer Isis

Pharmaceuticals and GlaxoSmithKline (GSK) have forged a collaboration to develop drugs for rare diseases that could earn the Carlsbad, California-based biotech up to $\$ 1.5$ billion dollars in licensing fees and milestones. London-based GSK will pay Isis $\$ 35$ million upfront and up to $\$ 20$ million for each of the six programs, which Isis has agreed to develop to proof of concept. Isis will apply its antisense-drug discovery platform to work on novel targets in new therapeutic areas, including infectious diseases and some conditions causing blindness. "The deal is emblematic of deals that financially sound companies can enter into," says Isis CFO and COO Lynne Parshall. "We can rely on longerterm royalties over the course of a drug's lifetime rather than bigger upfront licensing fees," says Parshall. Isis' pact with the pharma comes on the heels of encouraging phase 3 trial data for the cholesterolreducing antisense drug mipomersen that Isis is developing with its partner Genzyme (Nat. Biotechnol. 28, 295-297, 2010). The latest agreement underscores GSK's interest in nucleic acid-based therapeutics notes Lindsay Meyer, a senior consultant with Deloitte Recap, San Francisco. She highlights GSK's recent alliances with Regulus of Carlsbad, California, and Prosensa, of Leiden, The Netherlands, and earlier with Santaris in Hoersholm, Denmark. Isis, however, stands to benefit more than other companies that have licensed their RNA-based therapeutics to GSK, Meyer believes. Janelle Weaver

\section{Germany caps drug prices}

The German coalition government is putting into place new rules that will allow health insurers to influence the pricing of new medications. The changes are intended to save the healthcare system around $€ 2$ (\$2.7) billion) a year. "This could impact innovation, because cutting the price of drugs will reduce the incentives for biopharma companies to invest in R\&D," says Marion Kronabel, managing director of the European Association of Pharma Biotechnology, part of the European Federation of Biotechnology. Germany allows firms to set prices for branded drugs, and prices are higher than in most countries. Under the new rules, the branded drug sector will be allowed to set prices for their products only in the first year after launch. After this, drug firms and insurers will enter negotiations, overturning the industry's requests for two years' price protection. The new law, which will be enacted by the end of this year, could potentially trigger patent law changes to extend a drug's protection from generic competition, Kronabel believes. She also points at more pressing concerns, "Overall, this legal change and this approach for cost reduction will have less of a harmful influence on the biotechnology industry in Germany than the issue of taxes on $R \& D$ expenses and venture capital profits in Germany." Suzanne Elvidge 